\title{
Urban benchmarking: a managerial approach for better urban project. Cases : Rennes, Euralille, Bilbao and Constantine
}

\author{
MOUHOUBI Nedjima', SASSI BOUDEMAGH Souad ${ }^{2}$ \\ ${ }^{1}$ Abderrahmane Mira Bejaia University, Faculty of technology, Dept. Architecture, Bejaia, Algeria \\ ${ }^{2}$ Salah Boubnider University, LAVMF Laboratory, Faculty of Architecture and urbanism, Constantine, Algeria
}

\begin{abstract}
.
The fabric of the city has changed, not only because of urban development and rapid urbanization, but also because of knowledge and technologies evolution. The urban project is one of the new emerging practices. It is an approach aiming to better produce the city, but also extremely difficult to implement and Control on urban field. That's why a management of this approach is a necessary and the Benchmarking as a managerial tool, which aim to learning on the base of successful models, is to be explored. This paper aims to assess the Modernization Project of Constantine Metropolis (PMMC) in the light of successful urban projects which are the Rennes Urban Project, Euralille and Bilbao. it highlights the best practices from the study of these test benches. The results can help the implementation of urban projects and can serve as success factors in this process both in Algeria and in the world.
\end{abstract}

Keywords: project management; cities; urbanism; managerial comparison; success factors

\section{Introduction}

Given the scale of urbanization phenomenon, the opening of cities to global market, existing competition between them and the great place that they occupy in the global economy with the establishment of businesses and job creation, the need to build new management approaches and development of cities becomes obvious. A new urbanism arose in response to the sterility of previous planning schemes using the urban project as a tool. The urban project targets the city, using a new approach, that of the 'project' and not the plan. This approach projicio (which carries in itself the concept of the future) aims to combine strategic vision with specific actions and impregnates the local context while acting on the entire city. Thus, it combines economy and society as part of an intervention on space, while reaching the stream of sustainable development where the city is an ecosystem. It is the product of a political choice and benefits from its portage, however does not exclude the initiative and participation of the private sector and even users and city residents.

The urban project meets the challenges the modern city faces; among others: economic development, competition, competitiveness, attractiveness, good urban governance that supports the divergent interests of the city's producers while putting the inhabitant in decision-making position, and sustainable development. However, the practice of urban project is not well known, because of the complexity of the city itself. Thus, collective learning based on best practices derived from actual successful experiences of cities is needed. Thus, the objective of this article 
18-20 December, 2020

Oxford, United Kingdom

\section{$11^{\text {th }}$ International Conference on Humanities, Psychology \& Social Sciences}

is first, to situate an Algerian urban project which is the Constantine modernization project among successful urban projects in the world, namely the urban project of Rennes, Euralille and Bilbao, which are considered real lessons of urban project. Then make a list of best practices that can serve all urban projects.

The managerial approach "Benchmarking" which is a tool for both analysis and evaluation is the support of this research and achieves both two objectives.

\section{DATA AND METHOD}

\subsection{Presentation of Benchmarking}

The Benchmarking often refers to the concept of "best practice" and that of "comparative study". Its principle is to simply compare based on the best to correct errors, improve performance and innovate for better result.

The term Benchmarking is from the "benchmarks", an English word, it consists of "bench" which means "test bench" and "marking" meaning the "rating". So benchmarking is to identify and implement best practices approved and tested with the aim of finding a reference and implement for better performance and better results. The particular feature that benchmarking presents is that it is adaptable to many uses and can be personalized to each use. The urban benchmarking is a method used in urban field to allow a comparative analysis of a set of fundamental indicators between cities, regions or urban projects to soak for a better sustainable urban development.

The urban benchmarking relates to the identification of opportunity and strategic priorities to follow in cities. It reinforces, in particular, the principle of sustainable development, namely participation, since the dissemination of its results enables different stakeholders (decision makers, professionals, civil society ...) to take awareness of the issues, give advice based on reliable data and participate in decisions for development.

The Benchmarking method is composed of two phases: Bench and Marking. The "Bench" means the presentation of selected urban projects "test benches" based on indicators selected for evaluation, then the "marking" means the ratings of these indicators in relation to each bench, then compare these projects for evaluation and ranking of banks and finally the identification of good practices.

Thus, for the implementation of this method we took the following steps:

\section{Step 1: Determination of goals and objects of Benchmarking:}

$\checkmark$ Identification of objectives;

$\checkmark$ Determining the scope of the comparative analysis;

$\checkmark$ Determination of the indicators and the rating system;

\section{Step 2: data collection and representation of the results:}

$\checkmark$ Identify sources of information and data review;

Selection of indicators and their calculation for each test bench;

$\checkmark$ Presentation of results graphics 
18-20 December, 2020

Oxford, United Kingdom $11^{\text {th }}$ International Conference on Humanities, Psychology \& Social Sciences

$\checkmark$ Step 3: Interpretation of results and discussion

$\checkmark$ Evaluation of test benches and their classification

$\checkmark$ Identification of best practices

The subject of benchmarking is four urban projects that are:

$\checkmark$ In Algeria: the Modernization Project of Metropolitan Constantine PMMC;

$\checkmark$ In France: Rennes urban project; Euralille;

$\checkmark$ Spain: Bilbao Ria 2000;

This choice amounts, first of all, to the fact that the PMMC is one of urban pioneer projects in Algeria, and for other projects, they are considered among the most successful in the world Data collection method

For data collection, we relied on relevant literature (books, magazine articles and magazines), websites and forums of urban projects and the various interviews with players of the projects published in the press reviews or planning journals. In the Algerian case (PMMC), this data collection is consolidated by a content analysis (project documents, the specifications, contracts and program revisions), a survey with the departments in charge of the projects integrated into the PMMC; a citizen survey and interviews with elected officials and professionals directly related to the project and the development of its strategy.

\subsection{The indicators and the scoring system}

In our application of benchmarking, the system of indicators, which is an assessment tool but also decision support is a major aspect of benchmarking (the aspect of "Marking"), will be very useful for positioning and assess PMMC compared to other selected urban projects (test benches).

Indicators can be qualitative or quantitative; Benchmarking in our application, we focus on the managerial aspect of these projects, these indicators will be qualitative (Table1).

Table 1. Indicators and the scoring system used in the Benchmarking (Authors)

\begin{tabular}{|c|c|c|}
\hline Indicator & Definition of indicators & $\begin{array}{l}\text { Rating system: } \\
\text { Semantic Scale and } \\
\text { appreciation }\end{array}$ \\
\hline Strategy and ambition & $\begin{array}{l}\text { The will of political support or developers of the project } \\
\text { to make their cities better and towards what type of strategy } \\
\text { does that lead (open and attractiveness, out of urban crises } \\
\text {...). }\end{array}$ & \multirow{4}{*}{$\begin{array}{l}\text { Very strong }=4, \\
\text { Strong }=3 \\
\text { weak }=2 \\
\text { very weak = 1 } \\
\text { non existent=0 }\end{array}$} \\
\hline Project continuity & $\begin{array}{l}\text { the strategy is kept even in the long term and is } \\
\text { resistant to various changes that may affect the city, its } \\
\text { policy and project staff. }\end{array}$ & \\
\hline $\begin{array}{l}\text { stakeholder } \\
\text { involvement }\end{array}$ & $\begin{array}{l}\text { The project's ability to gather all stakeholders within a } \\
\text { framework of partnership and participation. }\end{array}$ & \\
\hline partnership & $\begin{array}{l}\text { The rate of involvement of the private sector in the } \\
\text { project (financing, production ...). }\end{array}$ & \\
\hline
\end{tabular}


HPSCONF

18-20 December, 2020

Oxford, United Kingdom $11^{\text {th }}$ International Conference on Humanities, Psychology \& Social Sciences

\begin{tabular}{|c|c|}
\hline citizen participation & $\begin{array}{c}\text { The participation and involvement of citizens and } \\
\text { residents in the project. }\end{array}$ \\
\hline $\begin{array}{c}\text { Information and } \\
\text { Marketing }\end{array}$ & $\begin{array}{c}\text { The dissemination of the project and its strategy at } \\
\text { multiple scales and the project marketing. }\end{array}$ \\
\hline $\begin{array}{c}\text { Management, } \\
\text { process, pilotage and } \\
\text { coordination }\end{array}$ & $\begin{array}{c}\text { Way and tools of management and project } \\
\text { management as well as coordination and pilotage } \\
\text { structures; }\end{array}$ \\
\hline $\begin{array}{c}\text { urban project mastery } \\
\text { The actor coalition taking responsibility to develop } \\
\text { and push through the urban project. }\end{array}$ \\
\hline
\end{tabular}

\subsection{Comparison Tools}

We developed graphic charts for comparison (Fig. 1) to facilitate the implementation of the benchmarking tool.

Figure 1: graphic charts for comparison template (Authors)

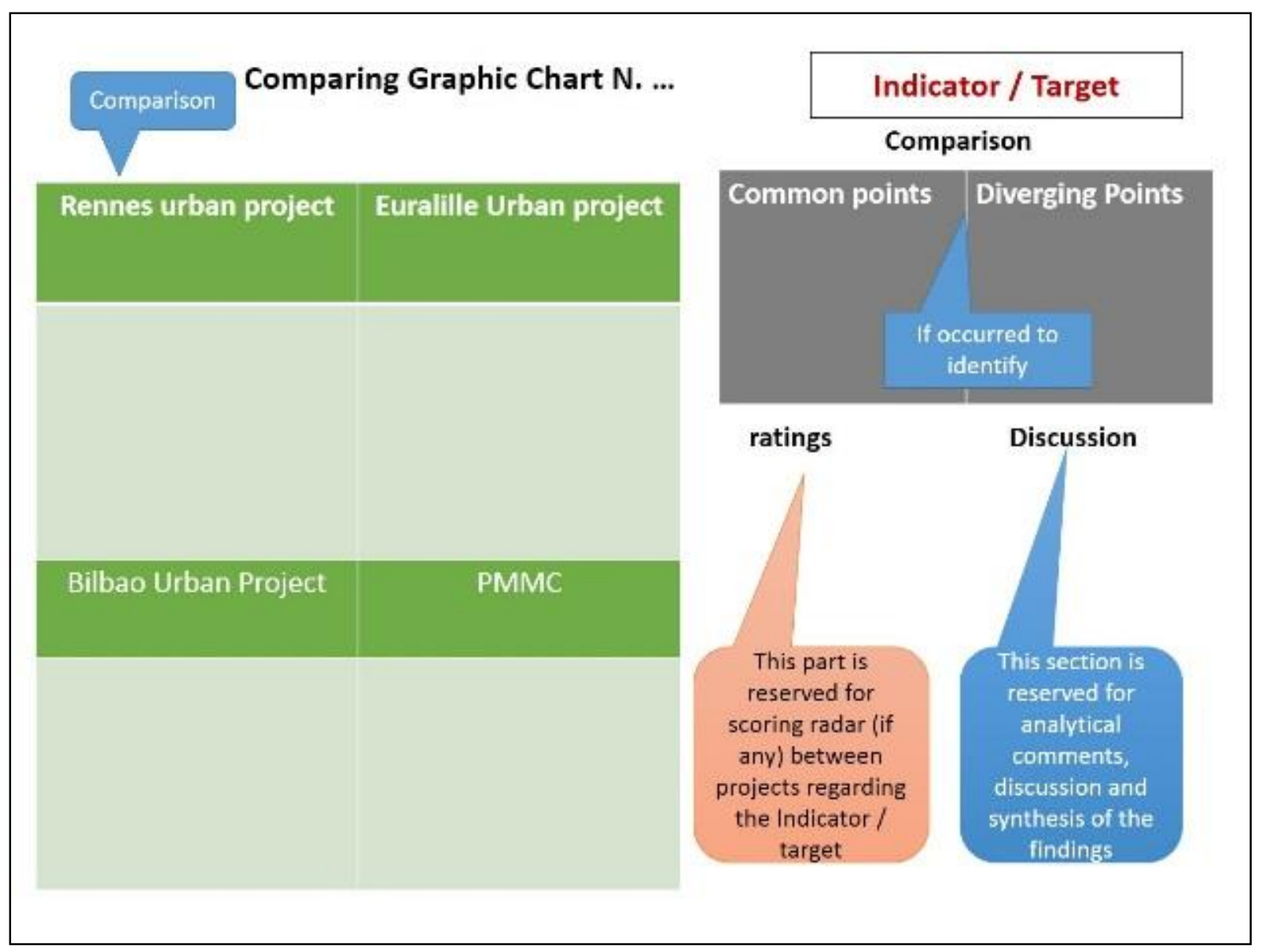


18-20 December, 2020

Oxford, United Kingdom $11^{\text {th }}$ International Conference on Humanities, Psychology \& Social Sciences

\section{RESULTS}

The results of the study and the discussions are presented in the following Comparison graphic Charters (fig 2, 3, 4, 5, 6, 7, 8, 9, 10, 11, 12, 13).

Figure 2. Comparison graphic Charter $N^{\circ} 1$ Context of occurrence of project and its objectives (Authors)

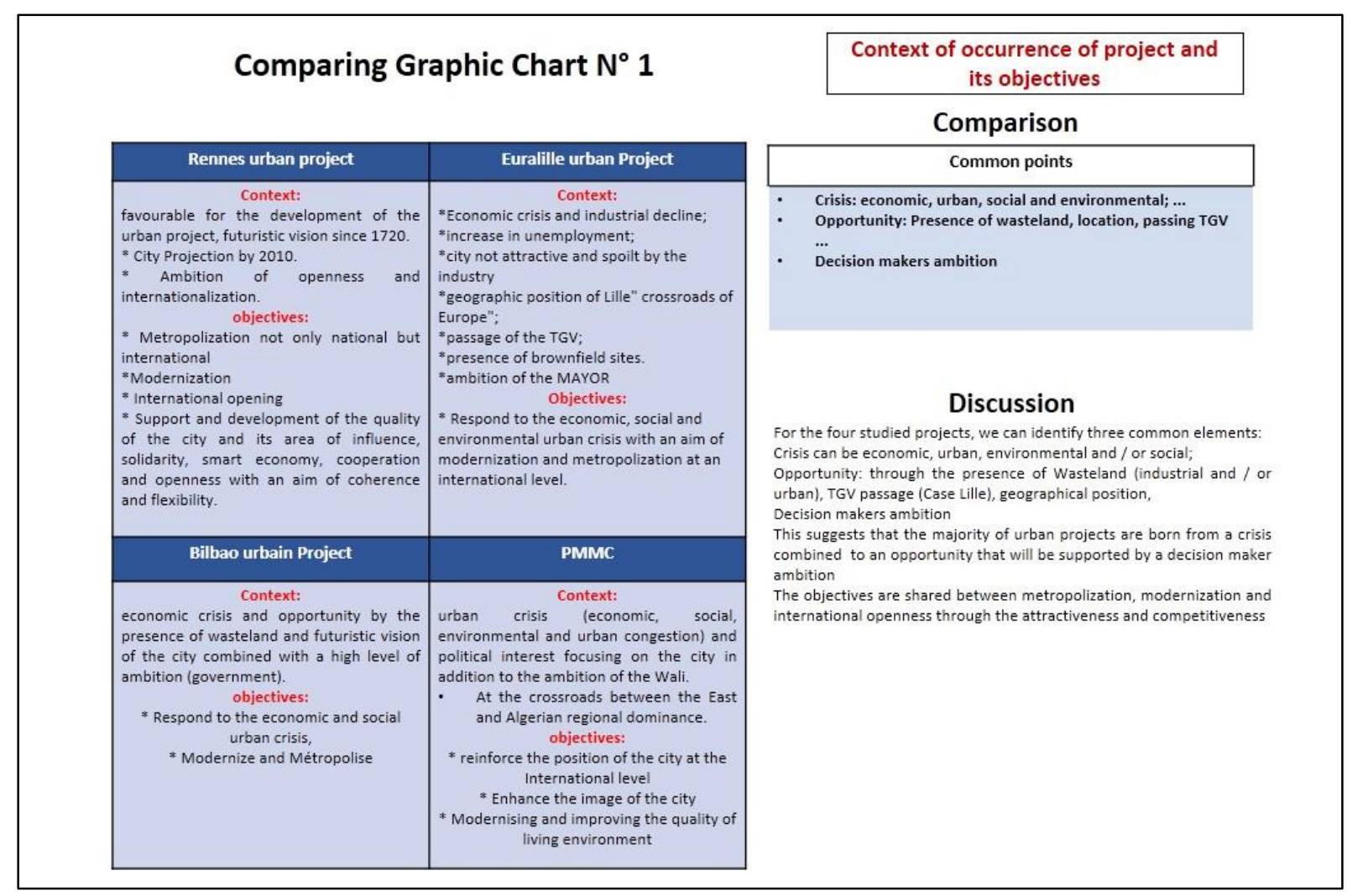


18-20 December, 2020

Oxford, United Kingdom $11^{\text {th }}$ International Conference on Humanities, Psychology \& Social Sciences

Figure 3. Comparison graphic Charter No. 2 Program (Authors)

\begin{tabular}{|c|c|c|}
\hline \multicolumn{2}{|c|}{ Comparing Graphic Chart $N^{\circ} 2$} & \multirow{2}{*}{$\begin{array}{r}\text { PROGRAM } \\
\text { Comparison }\end{array}$} \\
\hline Rennes urban project & Euralille urban Project & \\
\hline \multirow{2}{*}{$\begin{array}{l}\text { "Economic development; } \\
\text { "transportation; } \\
\text { " housing; } \\
\text { "the environment. }\end{array}$} & \multirow{2}{*}{$\begin{array}{l}\text { " transportation; } \\
\text { " housing; } \\
\text { " Offices } \\
\text { " the environment. }\end{array}$} & common points \\
\hline & & $\begin{array}{l}\text { the same sectors are covered by the modernization and } \\
\text { metropolization }\end{array}$ \\
\hline Bilbao urbain Project & PMMC & Discussion \\
\hline $\begin{array}{l}\text { *displacement of the harbor; } \\
\text { " Construction of the metro; } \\
\text { " Restructuration of railway lines; } \\
\text { " Expansion and modernization of the } \\
\text { airport; } \\
\text { " Comprehensive plan to clean Ria; } \\
\text { " Construction of the Guggenheim } \\
\text { Museum; } \\
\text { " Construction of the convention center } \\
\text { and Euskalduma music; } \\
\text { " Rehabilitation of the water front in the } \\
\text { Abandoibarra area; } \\
\text { "The revitalization of the Bilbao } \\
\text { neighbourhood Veija; } \\
\text { " Conversion of Ametzala sector; } \\
\text { "The functioning of Eusko Tram Bilbao } \\
\end{array}$ & $\begin{array}{l}\text { * Transport infrastructure } \\
\text { * University Infrastructure } \\
\text { " Tourism sector and the conditions of life } \\
\text { and comfort improvement } \\
\text { * Administrative Sector } \\
\text { " Culture } \\
\text { " Sports Sector }\end{array}$ & $\begin{array}{l}\text { The similarity between the programs of the projects analyzed leads us } \\
\text { to think that modernization is often forged in the same components } \\
\text { that relate to the modernization of the transport sector, improvement } \\
\text { of quality of life and comfort in the city, creating economic } \\
\text { attractiveness and promotion of investment and the creation of tourist } \\
\text { attraction across the cultural, leisure, hotels and for competitiveness } \\
\text { improved. }\end{array}$ \\
\hline
\end{tabular}




\section{HPSCONF}

\section{8-20 December, 2020 \\ $11^{\text {th }}$ International Conference on \\ Oxford, United Kingdom Humanities, Psychology \& Social Sciences}

Figure 4. Comparison graphic Charter No. 3 institutional recognition, institutional response scale (Authors)

\begin{tabular}{|c|c|c|}
\hline \multicolumn{2}{|c|}{ Comparing Graphic Chart $\mathrm{N}^{\circ} \mathbf{3}$} & $\begin{array}{l}\text { institutional recognition, institutional } \\
\text { response scale }\end{array}$ \\
\hline \multirow{3}{*}{\multicolumn{2}{|c|}{$\begin{array}{l}\text { We define institutional recognition and intervention scales, devices created for the } \\
\text { project and on what level it is recognized. }\end{array}$}} & Comparison \\
\hline & & Common points \\
\hline & & $\begin{array}{l}\text { "reconnaissance scales vary between local, national and } \\
\text { international. }\end{array}$ \\
\hline Rennes urban project & Euralille urban Project & \multirow[b]{4}{*}{$\begin{array}{l}\text { The recognition of urban projects at various urban and territorial levels } \\
\text { is important for their proper implementation. Thus, the urban projects } \\
\text { of Rennes, Lille and Bilbao have benefited from this key parameter of } \\
\text { success, while in the case of PMMC it is a key piece missing, especially } \\
\text { regarding land and financing of the project. }\end{array}$} \\
\hline $\begin{array}{l}\text { National and local: the project is } \\
\text { recognized as a project of national interest } \\
\text { for a better creation of partnerships and } \\
\text { fundraising. }\end{array}$ & $\begin{array}{l}\text { National and local: the project is } \\
\text { recognized as a project of national interest } \\
\text { better creation of partnerships and } \\
\text { fundraising. }\end{array}$ & \\
\hline Bilbao urbain Project & PMMC & \\
\hline $\begin{array}{l}\text { National: the State has recognized the } \\
\text { project as being of national importance; } \\
\text { and it has helped finance and facilitated } \\
\text { land mounting; } \\
\text { Regional and provincial levels: the province } \\
\text { has provided funding for several projects } \\
\text { (museum, convention center and metrol; } \\
\text { Local: local institutions have offered land } \\
\text { for the construction of the museum since } \\
\text { the project was recognized at all scales }\end{array}$ & $\begin{array}{l}\text { National: not recognized as a project of } \\
\text { national importance, however, the } \\
\text { president has demonstrated his interest in } \\
\text { the project, } \\
\text { Regional: declaration of general interest by } \\
\text { the wali only for the acquisition of land } \\
\text { under the project Bardo, not for PMMC; } \\
\text { Local: is not recognized }\end{array}$ & \\
\hline
\end{tabular}


18-20 December, 2020

Oxford, United Kingdom $11^{\text {th }}$ International Conference on Humanities, Psychology \& Social Sciences

Figure 5. Comparison graphic Charter $N^{\circ} 4$ the support in town planning instruments to the project (Authors)

\begin{tabular}{|c|c|c|}
\hline \multicolumn{2}{|c|}{ Comparing Graphic Chart N 4} & $\begin{array}{l}\text { the support in town planning } \\
\text { instruments to the project }\end{array}$ \\
\hline Rennes urban project & Euralille urban Project & Comparaison \\
\hline \multirow[b]{2}{*}{$\begin{array}{l}\text { * First urban plan the engineer ROBELIN } \\
\text { and the royal architect Jacques Gabriel in } \\
1723 \text {; } \\
\text { * The first master plan "urban" 1974; } \\
\text { * the master plan "green" in 1983; } \\
\text { * The agglomeration project; } \\
\text { * The third master plan 1994; } \\
\text { Charter commercial urban planning and plan } \\
\text { of urban transport (PDU) in 1996; } \\
\text { * Substitution of the master plan by a } \\
\text { Territorial Coherence Plan (SCOT) in 2000; } \\
\text { local development plan (PLU) to replace the } \\
\text { POS in } 2004 \text {. }\end{array}$} & \multirow{2}{*}{$\begin{array}{l}\text { ZAC Euralille; } \\
\text { ZAC Euralille } 2 \text {; } \\
\text { development program of public spaces } 2001 \text {; } \\
\text { ZAC Euralille } 3000 .\end{array}$} & Variation \\
\hline & & \multirow{3}{*}{$\begin{array}{l}\text { F The planning instruments available to the urban project or } \\
\text { created to support varies from one project to another, from non- } \\
\text { existence (PMMC) to the appointment of the project as a strategic } \\
\text { plan (Bilbao). } \\
\text { Discussion } \\
\text { The instrumentalization of the urban project is one of the } \\
\text { effective ways to implement it. The projects studied were } \\
\text { provided with planning instruments and urban planning to } \\
\text { better support urban project, except in the case of PMMC } \\
\text { which had no instrument dedicated to its urban project } \\
\text { approach. }\end{array}$} \\
\hline Bilbao urbain Project & PMMC & \\
\hline $\begin{array}{l}\text { The Bilbao urban project is at the crossroads } \\
\text { of several plans and planning instruments } \\
\text { made within its scope. so a formula is noted } \\
\text { "the project in plans and project as plans" } \\
\text { (CHADOIN and GODIER and TAPIE 2000. } \\
\text { P16) } \\
\text { * Strategic Plan: revitalization plan of the } \\
\text { urban area of Bilbao in } 1987 \text {; } \\
\text { * Agglomeration Strategic Plan on the } \\
\text { horizon of } 2000 \text { in } 1989 \text {. } \\
\text { * The general urban plan of Bilbao PUGB: } \\
\text { approved in } 1991 \text {; } \\
\text { * The strategic plan for the revitalization of } \\
\text { metropolitan Bibao: approved in 1992; } \\
\text { * Territorial Plan of Bilbao approved in } \\
\text { 1994; } \\
\text { * General Development Plan 2010: approved } \\
\text { in 2002. }\end{array}$ & $\begin{array}{l}\text { Apart from the project itself no instrument } \\
\text { has been implemented in order to facilitate } \\
\text { the project }\end{array}$ & \\
\hline
\end{tabular}


18-20 December, 2020

Oxford, United Kingdom $11^{\text {th }}$ International Conference on Humanities, Psychology \& Social Sciences

Figure 6. Comparison graphic Charter $N^{\circ} 5$ Strategy, ambition and foresight (Authors)

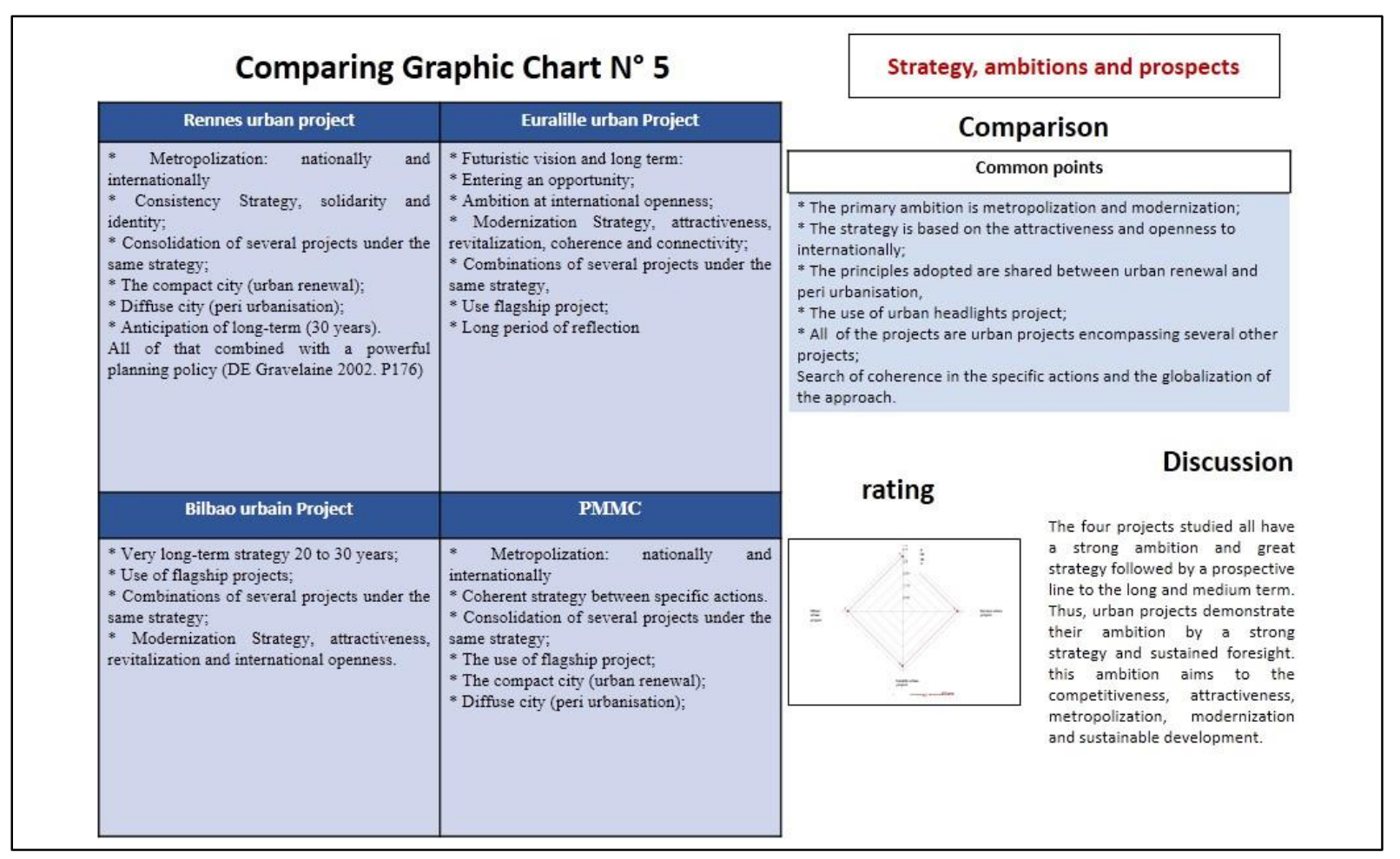




\section{HPSCONF}

\section{8-20 December, 2020 Oxford, United Kingdom}

$11^{\text {th }}$ International Conference on Humanities, Psychology \& Social Sciences

Figure 7. Comparison graphic Charter $N^{\circ} 6$ political support, continuity and multi temporality (Authors)

\begin{tabular}{|c|c|c|c|}
\hline \multicolumn{2}{|c|}{ Comparing Graphic Chart N 6} & \multicolumn{2}{|c|}{$\begin{array}{l}\text { political support, continuity and multi } \\
\text { temporality }\end{array}$} \\
\hline Rennes urban project & Euralille urban Project & \multicolumn{2}{|c|}{ Comparison } \\
\hline \multirow{4}{*}{$\begin{array}{l}\text { * Portage and strong political will (elected and } \\
\text { municipal); } \\
\text { * Administration restructuring for the Project; } \\
\text { * Decentralization and transversal approach; } \\
\text { * Continuity over } 30 \text { years; } \\
\text { * Solidarity between project stakeholders } \\
\text { (continuity factors); } \\
\text { * The Rennes urban project has been updated } \\
\text { several times in a sense of continuity, since } \\
\text { each update, it confirms the same foundation } \\
\text { and principles (DE Gravelaine 2002). Rennes } \\
\text { urban project is "remarkable first by its } \\
\text { continuity" (DE Gravelaine 2002. P176). }\end{array}$} & \multirow{4}{*}{$\begin{array}{l}\text { Very strong political support (Mayor P. } \\
\text { MAUROY knowing he has previously held key } \\
\text { positions with important mandate1973-2001) } \\
\text { * This portage was expanded to the urban } \\
\text { community and institutions (Lille Metropole, } \\
\text { Lille SAEM) } \\
\text { * Flexibility and adaptation to changes and } \\
\text { upheavals (new economic crisis) was always } \\
\text { required. the project since } 1989 \text { has created } \\
\text { attractiveness and adapt to change and reinvent } \\
\text { itself } \\
\text { * The contract as a tool fostered continuity; } \\
\text { * A juggling between the achievements of } \\
\text { temporality (short, medium and long term). }\end{array}$} & \multicolumn{2}{|c|}{ Common points } \\
\hline & & \multicolumn{2}{|c|}{$\begin{array}{l}\text { *The horizon of long-term strategies; } \\
\text { * Portage and strong political involvement of major bodies }\end{array}$} \\
\hline & & rating & \multirow{4}{*}{$\begin{array}{l}\text { Discussion } \\
\text { All of the studied urban } \\
\text { projects benefit from a } \\
\text { strong portage supported } \\
\text { by political bodies whose } \\
\text { rating is strong, like the } \\
\text { Bilbao urban project that } \\
\text { has benefited from a } \\
\text { strong porting extending } \\
\text { international political } \\
\text { bodies. } \\
\text { Continuity is strongly } \\
\text { present in European cases, } \\
\text { but low in the case of } \\
\text { PMMC because of political } \\
\text { instability, the duration of } \\
\text { the mandate, the events } \\
\text { and the lack of tools for } \\
\text { this continuity (Contract, } \\
\text { Charter...) }\end{array}$} \\
\hline & & \multirow{3}{*}{ 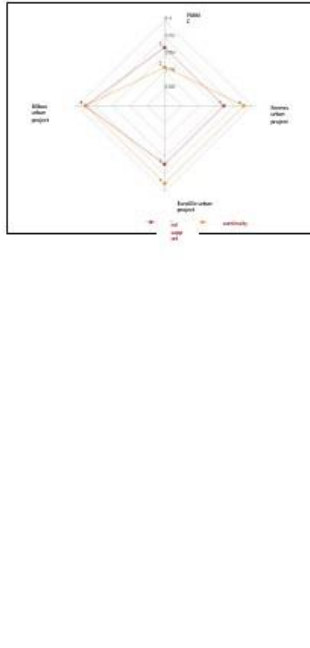 } & \\
\hline Bilbao urbain Project & PMMC & & \\
\hline $\begin{array}{l}\text { * The urban project of Bilbao was supported by } \\
\text { a plurality of actors, namely the municipality of } \\
\text { Bilbao, the government of the Basque region, } \\
\text { the Spanish State and the European union. } \\
\text { Thus, its Portage is of great strength and } \\
\text { Influence both political and financial. } \\
\text { * Continuity was created through the } \\
\text { independance and adaptation to change by } \\
\text { Bilbao Ria } 2000 \text { and Metropoli } 30 \text {. The urban } \\
\text { project plays on all ranges of time, in order to } \\
\text { adapt the uncertainties of market and policy } \\
\text { schedules (CHADOIN and GODIER and } \\
\text { TAPIE 2000. P51). } \\
\text { * "Another key feature of the project is its } \\
\text { temporality, long temporality punctuated by } \\
\text { planning process more or less related ... and ... } \\
\text { achievement-events" (ibid. P49) }\end{array}$ & $\begin{array}{l}\text { * The PMMC was supported by the Wali of } \\
\text { Constantine and the support of the president, } \\
\text { howeverdue to lack of Term, policy changes } \\
\text { and events, project continuity was not assured. }\end{array}$ & & \\
\hline
\end{tabular}



Humanities, Psychology \& Social Sciences

Figure 8. Comparison graphic Charter $N^{\circ} 7$ Actors, partnership and participation (a) (Authors)

\begin{tabular}{|c|c|c|c|}
\hline \multicolumn{2}{|c|}{ Comparing Graphic Chart $N^{\circ} 7$} & \multicolumn{2}{|c|}{ Actors, partnership and participation } \\
\hline Rennes urban project & Euralille urban Project & \multicolumn{2}{|c|}{ Comparison } \\
\hline \multirow{4}{*}{$\begin{array}{l}\text { * The actors are all involved: Elected } \\
\text { officials, technicians, Administrations, the } \\
\text { urban community and the Inhabitants; } \\
\text { * Cooperation and dialogue are established; } \\
\text { " The "District" tool ensures this } \\
\text { cooperation and dialogue. Indeed; "Each } \\
\text { project is studied through dialogue between } \\
\text { inhabitants, elected prime contractor" (DE } \\
\text { GRAVELARN 2002) } \\
\text { "The partnership is low but present, }\end{array}$} & \multirow{4}{*}{$\begin{array}{l}\text { * Involvement of all stakeholders (local authorities, } \\
\text { town and urban community, the Municipality of } \\
\text { Lille, SAEM, Lille-Métropole) } \\
\text { * Creation of a multitude of structures for } \\
\text { coordination, management and partnership the } \\
\text { urban community, the Agency for International } \\
\text { Promotion of the Metropolis MIIA), the Euralile- } \\
\text { Metropole company and limited company of mixed } \\
\text { economy (SAEM)); } \\
\text { * The use of contracts to ensure build a strong } \\
\text { partnership; } \\
\text { * "Circle of architectural and urban quality" for } \\
\text { better coordination and better monitoring; } \\
\text { * Assistance to project ownership and delegation of } \\
\text { authority; } \\
\text { * For PPP, SAEM Lille metropolis and have to } \\
\text { ensure the creation of investment and PPP; }\end{array}$} & \multicolumn{2}{|c|}{ Common points } \\
\hline & & \multicolumn{2}{|c|}{$\begin{array}{l}\text { * The involvement of all actors and the creation of structures } \\
\text { mediating and coordinating except in in the PMMC. }\end{array}$} \\
\hline & & rating & \multirow{4}{*}{$\begin{array}{l}\text { Discussion } \\
\text { For the actors, and after } \\
\text { scoring, only the PMMC is } \\
\text { ranked low and this } \\
\text { because of the non } \\
\text { involvement of al } \\
\text { stakeholders; while the } \\
\text { top of the ranking is the } \\
\text { project of Bilbao thanks to } \\
\text { the strong involvement o } \\
\text { its players. The use o } \\
\text { dialogue and cooperation } \\
\text { to manage this } \\
\text { involvement is strongly } \\
\text { present in the Europear } \\
\text { case. } \\
\text { The partnership is very low } \\
\text { in the PMMC, strong in the } \\
\text { case of Lille and Rennes } \\
\text { and very strong in the case } \\
\text { of Billio thanks to the } \\
\text { various stakeholders and } \\
\text { management as part o } \\
\text { Billbao Ria 2000. }\end{array}$} \\
\hline & & \multirow{3}{*}{$\begin{array}{r}\equiv+\cdots=- \\
=-\ldots=-\end{array}$} & \\
\hline Bilbao urbain Project & PMMC & & \\
\hline $\begin{array}{l}\text { * Involvement of various actors with strong } \\
\text { political backing; followed by effective } \\
\text { financial and land management with the } \\
\text { creation of Bilbao Ria } 2000 \text { and Metropoli } \\
30 \\
\text { " Partnership PPP highly developed thanks } \\
\text { to these two structures and "cross funding } \\
\text { are used for each type of shares or urban } \\
\text { operations, cultural and infrastructure" (O. } \\
\text { CHADOIN and GODIER and TAPIE 2000. } \\
\text { P19) }\end{array}$ & $\begin{array}{l}\text { * The project stakeholders are all involved; } \\
\text { * The partnership is very low (only in building } \\
\text { hotels in the Accord group and the tram) }\end{array}$ & & \\
\hline
\end{tabular}


18-20 December, 2020

Oxford, United Kingdom $11^{\text {th }}$ International Conference on Humanities, Psychology \& Social Sciences

Figure 9. Comparison graphic Charter $N^{\circ} 8$ Actors, partnership and participation (b) (Authors)

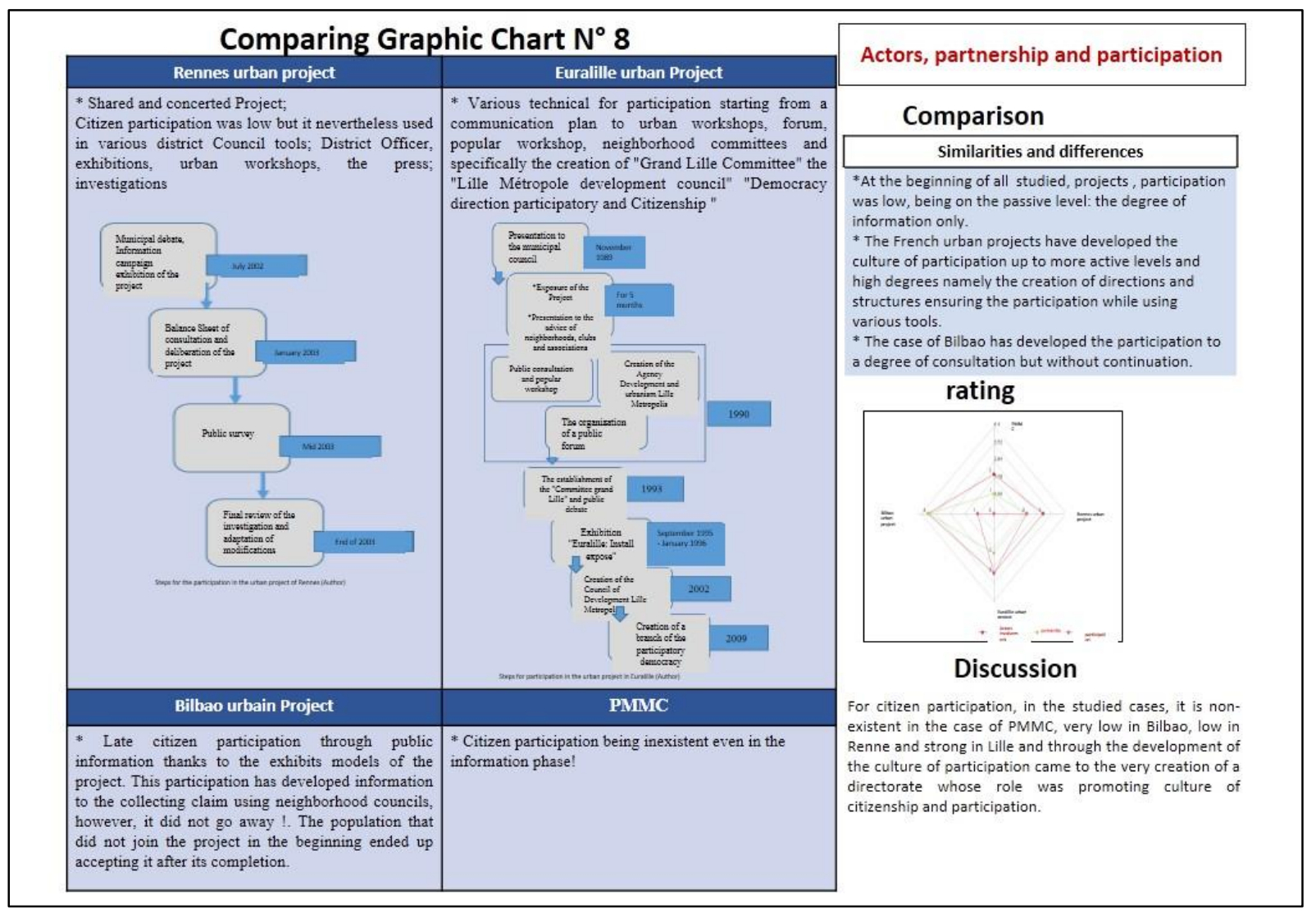


18-20 December, 2020

Oxford, United Kingdom $11^{\text {th }}$ International Conference on Humanities, Psychology \& Social Sciences

Figure. 10. Comparison graphic Charter $N^{\circ} 9$ finance and land mounting (Authors)

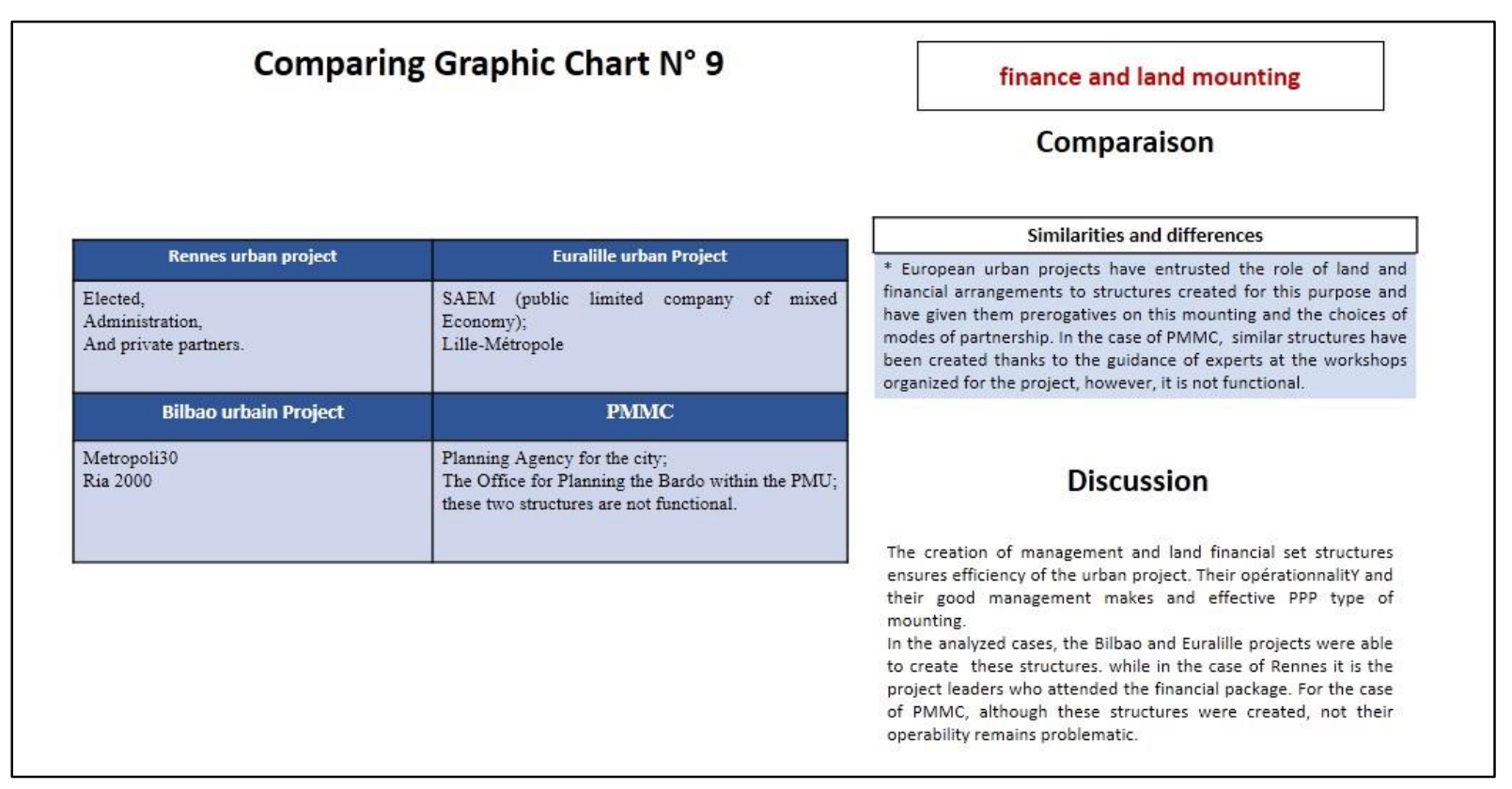


18-20 December, 2020

Oxford, United Kingdom $11^{\text {th }}$ International Conference on Humanities, Psychology \& Social Sciences

Figure 11. Comparison graphic Charter $N^{\circ} 10$ Information and Marketing (Authors)

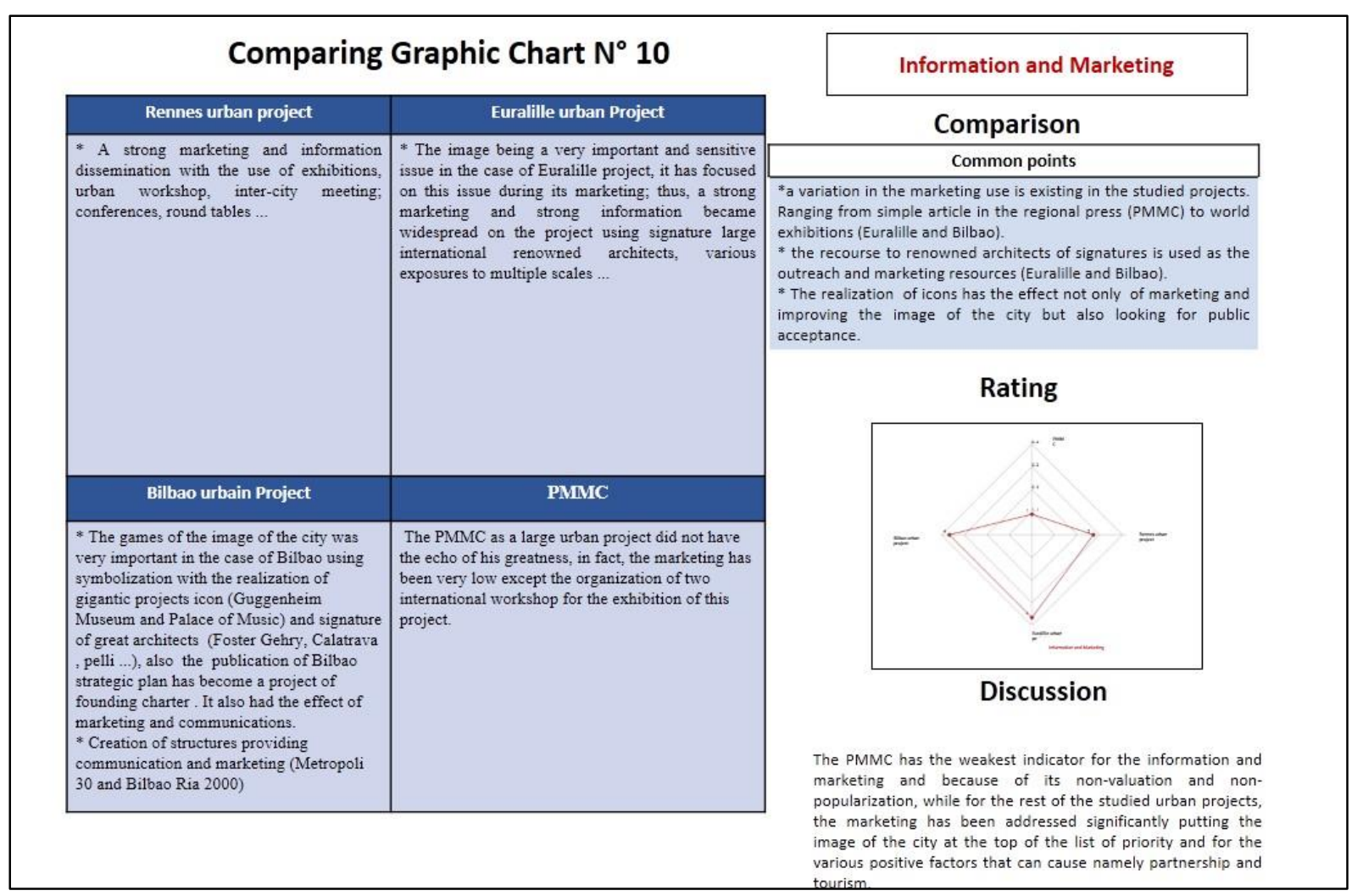


18-20 December, 2020

Oxford, United Kingdom $11^{\text {th }}$ International Conference on Humanities, Psychology \& Social Sciences

Figure 12. Comparison graphic Charter $N^{\circ} 11$ Management, process, pilotage and coordination (Authors)

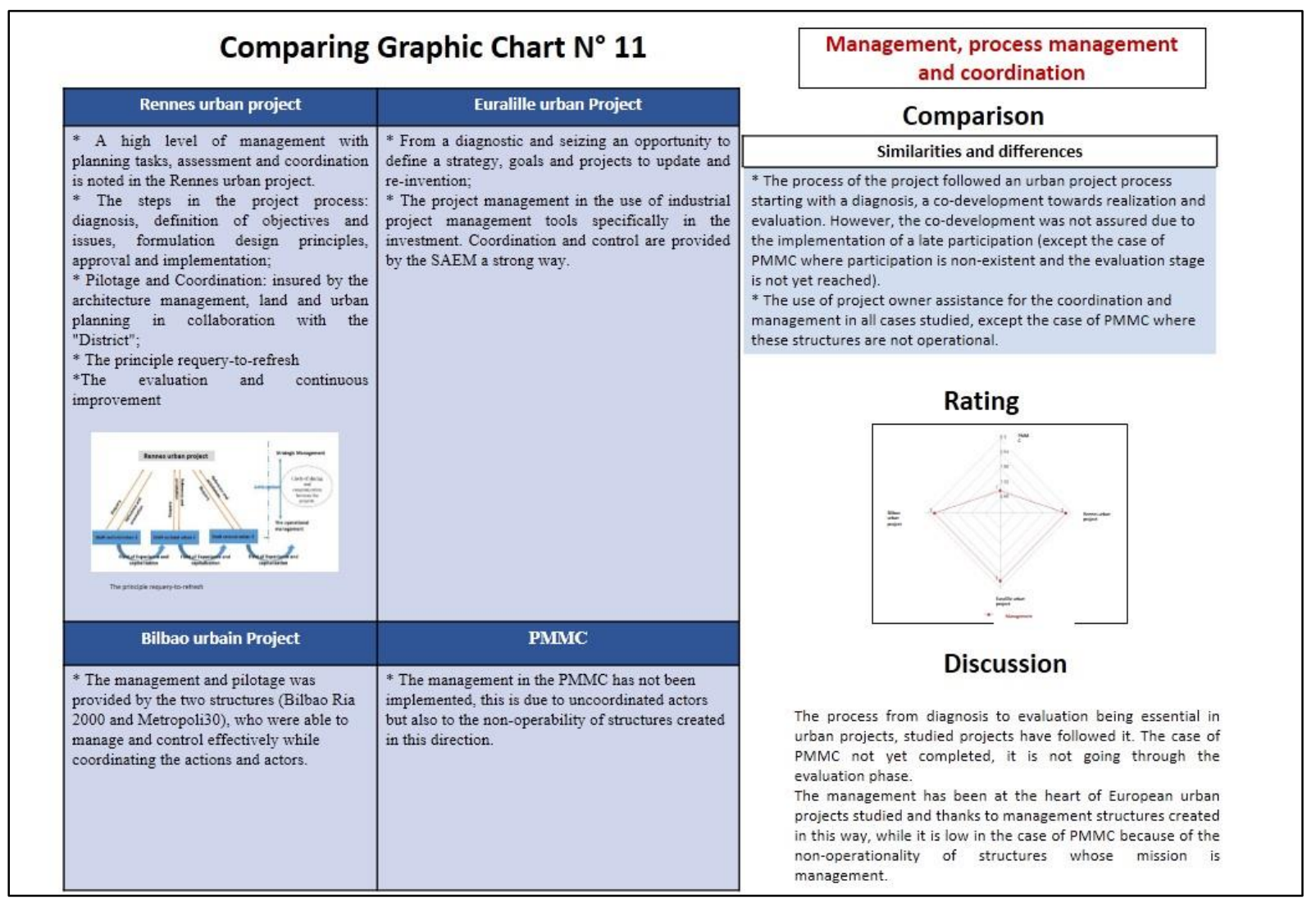


18-20 December, 2020

Oxford, United Kingdom $11^{\text {th }}$ International Conference on Humanities, Psychology \& Social Sciences

Figure 13. Comparison graphic Charter $N^{\circ} 12$ urban project mastery (Authors)

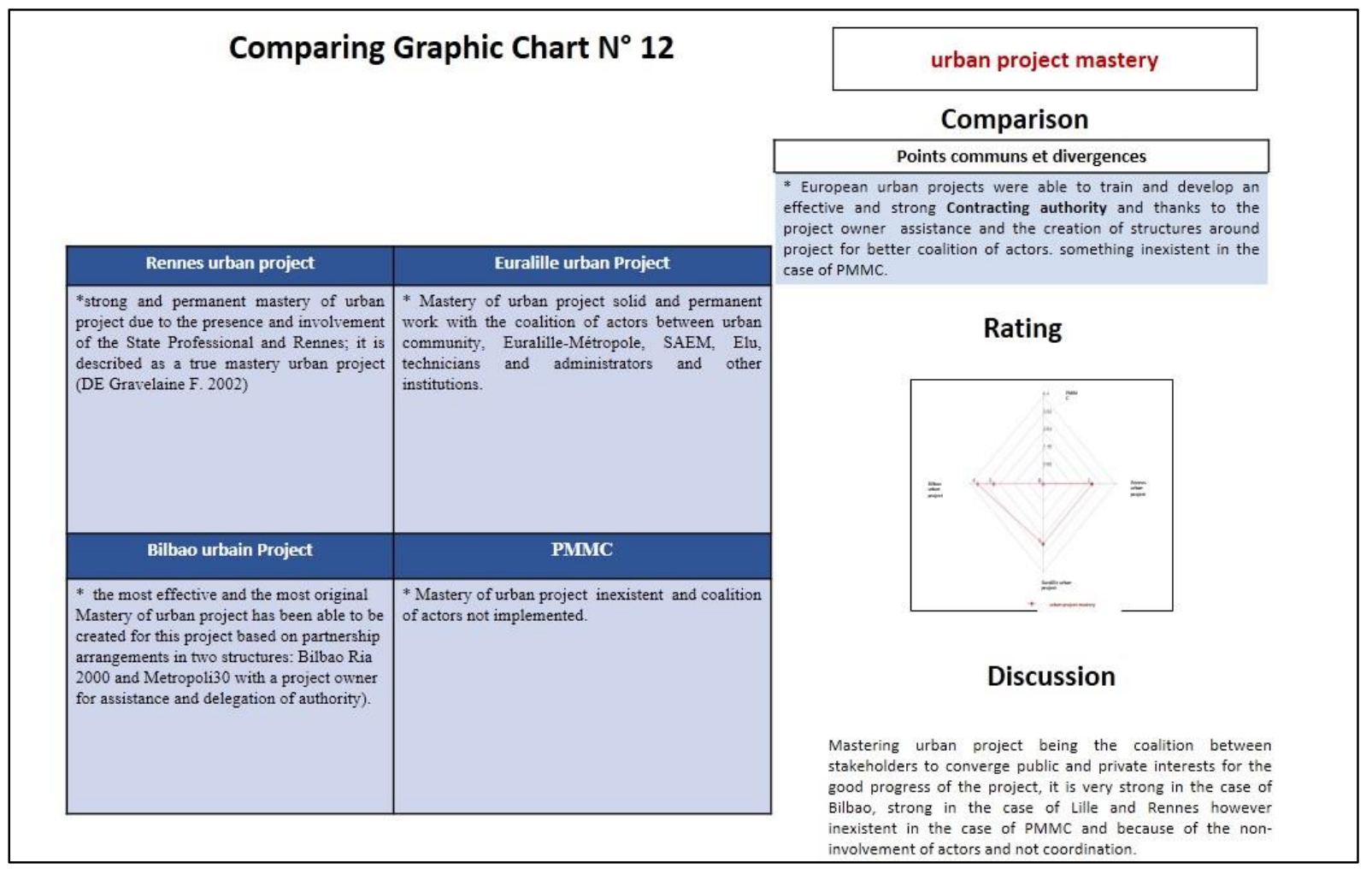


18-20 December, 2020

Oxford, United Kingdom $11^{\text {th }}$ International Conference on Humanities, Psychology \& Social Sciences

\section{DISCUSSION: From comparison to the lessons, best practices Benchmarking}

Having set on step Benchmatrking we arrived at detecting best practices for test benches that we used in this benchmarking. Even though, as described by FIRLEY and GRON "It is not an easy task to generalize the outcome of our comparative studies and It Would be foolish to currency universal step-by-step guide to the process of Master-planning" (FIRLY \& GRON, 2013. P21) we can name the following:

- The urban project certainly needs ambition and strong political support. In fact, as expressed A. MASBOUNGI "in the absence of a project leader, a policy maker capable of making bold decisions, no project can really emerge.". All the studied urban projects enjoy a strong political support, however, Euralille, Rennes and Bilbao projects were able to invent and create a method of design and implementation that accompanies this ambition and this portage through the identification and analysis of existing spatial elements, but also the mobilization of resources and actors. However, the PMMC failed to take advantage of this portage and this great ambition.

The political support of the urban project is one of the determining factors in its success. The mandates of the Mayor or Wali being limited may be a hindrance and a constraint. Thus, the example of Euralille is very enriching on this point, since the Mayor Pierre Mauroy has long been the Mayor of the city and could carry his project and his ambition till the end. Knowing also that even after the end of his term in 2001, he remained at the heart of the project through its continuous involvement in its implementation qs president of Lille Métropole urban community until 2008.

The example of Bilbao Ria 2000 model not only allows a good management of the urban project, but also a non-dependence of politics changes, using autonomous management, funding not dependent on cyclical budget and commitment over the long term, (ALAYO, 2008). Without forgetting the various continuity tools that may exist which test benches in this bechmarking have used, namely city contracts, charters and advocacy coalitions (LA SAEM, Bilbao Ria 2000 ...). Indeed, "the formulation of charters, plan or other document evidencing helps mobilize political representatives from several local authorities, private investors, developers, lobbyists, around common values that transcend the only particular interests." (CHADOIN O et al., 2000. P216).

Also, the structure of government is crucial in the political support, in the case of Constantine, elected officials and administrations were not kept informed nor involved in the project from the beginning, so they are not carriers or consolidators of project. while in the example of Rennes, the urban project has even led to a municipal restructuring and administrations have become carriers of the project.

Indeed, the mastery of urban project is one of the successful urban project keys. Its ability to create coordination and complicity between the various project stakeholders is a necessity. We can mention the urban project of Montpelier and Bilbao that have a dynamism which gave witness of "the presence of a strong project owner, ensuring the sustainability of projects and able to manage change" (ROUX, 2001. P61). Besides, the urban project of Bilbao has put up an original mastery of project structure compared to other urban projects. The latter is responsible for the design, and managing various operations and coordination of actors (OTAOLA, 2001). 


\section{8-20 December, 2020}

\section{Oxford, United Kingdom}

\section{$11^{\text {th }}$ International Conference on Humanities, Psychology \& Social Sciences}

The latter (players) need to be able to come together to the same objectives and to build trust and create consensus because "if the project does not move is that the people involved do not know how to work together. It suffices they learn! "(JOLY \& MULLER, 1994. P XVI).

The case of Euralille is also very demonstrative, regarding to this aspect, through the creation of the quality circle and collaboration among all stakeholders. The political support is not only source of ambition and determination, it is also necessary that this portage can join forces and actors and the resources needed for the project. Mayor Euralille "... had federated the forces of the city (political, economic and trade union)" (EURALILLE, chronique d'une métropole 2008. P19), and it is this element, in major part, which Euralille is a success today. As the urban project of Bilbao has managed to dismantle the importance of collaboration and consensus among stakeholders through the structure created in this framework (Bilbao Ria 2000 and Metropoli 30) and are both organizational arrangements and coordination financial management instruments.

One element to highlight is the extensive decentralization in the case of Bilbao and Lille while in the case of PMMC it is restricted, which is why the funding and fundraising were difficult. In the case of Bilbao, the Basque policymakers are convinced that decentralization is a project success factor for them decentralization promotes and regulates proximity control between administrations "(ORMAZABAL P, 2001).

For large projects of major investments, major measures but also great sacrifices; the Spanish State has been able to detect the importance of the project revet Bilbao, not only regionally but also nationally and internationally. So he took measures of the size of this project, namely, the declaration of the project as a priority of national importance and then the mobilization of financial funds for its implementation while ensuring ease of land acquisition. However, for the PMMC, even though it had strong political backing and support of the President, the steps towards facilitation of its implementation have not been at the level of his ambition, such as project has not been recognized as being of national interest. This has greatly affected facilitating its implementation. The most glaring example is the land acquisition problem for Bardo Viva-City. Compared to urban project in Bilbao, it has managed through a land release strategy and through large infrastructure build a land assembly facilitating the realization of various operations of the project.

For large projects, major investments. Find financing urban projects is difficult but an imperative task, the private involvement became obvious. Urban projects that we used for benchmarking have all used the PPP process. The example of Euralille is also very illustrative for this dimension, as most parts of the projects and operations were as a partnership between Public and Private.

The opening of the private political funding and partnership, in all its forms, is a key success factor for urban project, which is the case in Bilbao. This one required investments that neither the province nor the state could finance (at least in record time) nor what is not the case in the PMMC yet in its initial program, involving the private was considered an imperative. The creation of an inter-company "Ria 2000" in the case of Bilbao is an element that actively participated in the project and in the transformation of the city. Marketing plays a very important role regarding the attractiveness of investors but also tourists. The signature of the great architects combined with innovative ideas has made Bilbao a tourist destination but also a dispute of land to investors. 


\section{HPSCONF}

\section{8-20 December, 2020}

\section{Oxford, United Kingdom}

\section{$11^{\text {th }}$ International Conference on Humanities, Psychology \& Social Sciences}

Marketing and brand games and image of the city is important in the cycle of the urban project, the PMMC failed to implement a marketing device that can ensure the promotion of the city at large scale compared Lille and Bilbao through architectural debates, international exhibitions and information broadcasts were able to get a place in the tourist guides and the news pages.

The relationship between management dimensions (strategic and operational) is a criterion that facilitates the implementation and proper conduct of the execution of the urban project process. The Rennes urban project has demonstrated that this aspect can be a support for the urban project approach through the principle of reinterrogation-actualization. And continuous improvement is always required. In the case of Bilbao creation of Bilbao Ria 2000's main objective is this articulation as it is considered an operational implementation instrument of major urban projects.

The concurrent engineering that results in coordination between actors and collaboration as well as the mastery of urban project is success factor in any project. The examples reviewed integrate all these elements and make them the principles to make their approach and project implementation process effective and efficient. Listening, coordination, negotiation, consensus are crucial.

Assessment is a step often overlooked in many projects. The majority of projects studied in this Benchmarking incorporate this step as a criterion that allows progress and not as a waste of time. This assessment should be both interactive and prospective to allow continuous improvement and a critical look at the project.

The events are important in the promotion of a city. Cities used this to promote their urban projects such as Lille was designated capital of European culture in 2004; its urban project enabled it to get ready for this event.

Finally, the failure can only be constructive, urban Euralille project was able to raise even after a crisis. Indeed, the revival of Euralille through the urban project Euralille 2 demonstrates that it must assimilate experiences of the past to build the future. Thus, continuity combined with continuous improvement can also be an asset for the urban project. This is the perspective and the guideline that can fix the PMMC order to be reborn and recover.

\section{CONCLUSION}

In this article, there was talk of a common learning and transfer from knowledge between four urban projects based on benchmarking.

This management approach, based on the comparison, was a support of our study to evaluate the approach of the urban project in Algeria based on the example of PMMC and support for the development of a best from list practices learned from the study of successful cases from three cases of considered successful urban project.

Finally, the conclusion that is offered to us is that this list can and should be personalized for every single project since the urban context and objectives differ. However, the basic principles of success it remains divided between adherence of actors with broad participation and a heavy partnership, the strength of political support and the implementation of an adequate management system providing both strategic level operational project. 
18-20 December, 2020

Oxford, United Kingdom $11^{\text {th }}$ International Conference on Humanities, Psychology \& Social Sciences

\section{Reference}

[1] ALAYO, J. (2008). L'expérience de BILBAO Ría 2000 : La régénération urbaine de la métropole de Bilbao. In Forum Régional des Acteurs de la Rénovation Urbaine, Bilan 2008 de l'animation du réseau des acteurs. ANRU - FORUM REGIONAL. Marseille. 29 avril 2008.

Available: http://www.anru.fr/fraru/fraru2008/Marseille/Plenieres/Grand_Temoin_Bilbao_J_Alayo.p df.

[2] ASCHER, F. (2001). Les nouveaux principes de l'urbanisme, Ed. L'Aube.

[3] CHADOIN O. GODIER P and TAPIE G. (2000). Du politique à l'œuvre : Bilbao, Bordeaux, Bercy, San Sebastian. Système et acteurs des grands projets urbains et architecturaux. Ed. De l'aube. France. 237P.

[4] SAEM. (2008). EURALILLE, chroniques d'une métropole en mutation (1988-2008). Ed. Dominique CARRE.

[5] FIRLY, E. and GRON, K. (2013). The urban Master-planning handbook. Ed. John Wiley . $287 \mathrm{P}$.

[6] JOLY, M. and MULLER, J. L. (1994). De la gestion de projet au management par projet. Ed. AFNOR. Paris. 213P.

[7] ORMAZABAL, P. (2001). La rénovation urbaine, engament du gouvernement basque. In PROJET URBAIN (N²3) (septembre 2001) «Bilbao, la culture comme projet de ville ». PP 26-29.

[8] OTAOLA, P. (2001). Bilbao Ria 2000 In MASBOUNGI A. (coord.), Fabriquer la ville. Outils et méthodes : les aménageurs proposent. Paris, La Documentation française, pp. 149150 .

[9] ROUX, J.M. (2001). Projets durables et de longue durée : expérimentations et innovations dans la conception et le management In MASBOUNGI A. (coord.), Fabriquer la ville. Outils et méthodes : les aménageurs proposent. Paris, La Documentation française, pp. 5162. 